\title{
粚
}

\section{Kanker as lewensnood: voorlopige merkers vir die pastoraat}

\author{
A.R. Brunsdon \& G.A. Lotter \\ Praktiese Teologie \\ Potchefstroomkampus \\ Noordwes-Universiteit \\ POTCHEFSTROOM \\ E-pos: arbrunsdon@gmail.com \\ George.lotter@nwu.ac.za
}

\section{Abstract \\ Cancer as a life crisis: preliminary markers for the pastorate}

The diagnosis of cancer is embedded in the negative social discourse of a death sentence. It therefore creates an existential crisis in the lives of its victims. This article will explore the pastoral implications of a cancer diagnosis. Whereas the medical path becomes clear upon the diagnosis of a particular type of cancer, the pastoral path may not immediately be evident. By viewing cancer phenomologically and in the light of the most common medical treatment, the article will try to establish what key issues (changes) would be brought upon persons affected by cancer. Eight key issues are taken into consideration: the change of short and long-term goals, the exposure to new relationships, feelings of rejection, an identity crisis, a radicalisation of communication, a new perspective on time, death-anxiety and faith issues. In the light of these anticipated key issues, six focus areas are identified as preliminary markers for the pastoral process. The problem of theodicy, suffering, the relationship between sin and illness, ethical issues of a medical nature, end of life counselling and eschatological perspectives are taken into consideration as areas that would be of great value in the pastorate to persons affected by cancer.

\section{Opsomming}

\section{Kanker as lewensnood: voorlopige merkers vir die pastoraat}

Die diagnose van kanker is ingebed in die negatiewe sosiale diskoers van 'n doodsvonnis. Dit het derhalwe 'n eksistensiële krisis tot gevolg in die lewens van persone wat daardeur geaffekteer word. Waar die mediese wetenskap sy optrede laat 
bepaal deur die tipe kanker wat gediagnoseer is, is die roete wat die pastoraat moet volg nie dadelik duidelik nie. In hierdie artikel word gepoog om voorlopige merkers te identifiseer wat van belang sal wees vir die pastoraat aan persone wat deur kanker geaffekteer is. Deur kanker fenomenologies te beskou en ook in die lig van die bekendste vorme van mediese ingrype, sal sekere sleutelveranderings geponeer word wat vermoedelik deur 'n kankerdiagnose meegebring sal word. Agt geantisipeerde sleutelveranderings word bespreek, te wete: die verskuiwing van grense, blootstelling aan nuwe verhoudings, gevoelens van verwerping, 'n identiteitskrisis, die radikalisering van kommunikasie, die radikalisering van tyd, skeidings- en doodsangs asook geloofsvrae. In die lig van hierdie geantisipeerde veranderings word 'n sestal voorlopige fokusareas vir die pastoraat bespreek. Die teodiseevraag, lydingsvraagstuk, die sonde-siektevraagstuk, medies-etiesevraagstukke, sterwensbegeleiding en rousmart asook die eskatologiese bestemming van die gelowige. Hierdie aspekte kom in aanmerking as voorlopige merkers vir die pastoraat aan persone wat deur kanker geaffekteer is.

\section{Inleiding}

Die siekteverskynsel kanker is ingebed in die negatiewe sosiale diskoers van 'n doodsvonnis (Crafford, 2004:573; Meunier, 2007:1). Dit veroorsaak derhalwe 'n eksistensiële krisis waar dit ook al voorkom.

Selfs in die Skrif word dit as 'n vernietigende mag aangedui. Krüger (1987:74) vertaal byvoorbeeld die begrip bederf, soos aangetref in Habakuk 3:16 (OAV, 1953), letterlik met die woord kanker. In die Nuwe Testament (OAV, 1953; NAV, 1983) gebruik Paulus die uitdrukking kanker (Grieks: gaggraina) in 2 Timoteus 2:17 om die vernietigende mag van die dwaalleer van Himeneus en Filetus toe te lig. Die persepsie dat kanker 'n destruktiewe fenomeen verteenwoordig, is dus oor baie jare vasgelê in bykans alle kulture.

\section{Navorsingsprobleem, doelstelling en metode}

Die hooffokus van die navorsing is dit wat kanker as lewensnood konstitueer en waarop die pastorale proses sal moet fokus. Met 'n diagnose soos bors- of kolonkanker is die mediese uitdaging afgebaken, maar watter pastorale vraagstukke word deur kanker geïmpliseer? Die navorsing sal poog om voorlopige merkers vir die pastoraat aan te dui. Dit beteken dat die pastorale fokusareas wat deur die navorsing blootgelê sal word waarskynlik nie die enigste 
fokusareas vir die pastoraat sal verteenwoordig nie. Ander fokusareas sal deur verdere navorsing geïdentifiseer kan word.

Die navorsingsvraag sal aan die orde kom deur kanker fenomenologies te beskou. Hiermee sal ook die mediese ingrype wat met kanker geasossieer word aan die orde kom. Op grond hiervan sal die belangrikste veranderings wat die kankerverskynsel in die lewens van pasiënte meebring, gekonkretiseer word, om sodoende die uitdagings vir die pastoraat bloot te lê.

Die navorsing vertrek vanuit 'n diakoniologiese epistemologie. Dit beteken dat die Skrif as uitgangspunt vir die beredeneerde pastorale merkers dien met inagneming van metateoretiese insette vanuit ander dissiplines soos die mediese wetenskap. Die pastoraat aan die persoon deur kanker geaffekteer, word derhalwe binne die raamwerk van hierdie navorsing beskou as geloofshulp wat uitloop op lewenshulp. Hierin word aansluiting gevind by Louw (1998:58), wat die eiesoortige karakter van die pastorale hulpverlening nie in die eerste plek in die metodiek daarvan vind nie, maar in die heil van Christus soos geopenbaar in die Woord. Hierdie heil word deur God se genadeverbond met die mens onderlê en vorm die basis van pastorale betrokkenheid by die mens in nood (vgl. Van Pelt, 1999: 285 e.v.).

\section{Kanker fenomenologies beskou}

In die volgende paragrawe sal kanker as fenomeen in oënskou geneem word ten einde die identifisering van uitdagings vir die pastoraat in die hand te werk. Geen aanspraak op mediese volledigheid word gemaak nie, aangesien die skopus van hierdie artikel nie medies van aard is nie, maar teologies.

\subsection{Oorsaaklike faktore van kanker}

Omdat die presiese oorsprong van kanker onbekend is, is dit fenomenologies in 'n wolk van misterie gehul en die mediese stryd daarteen ver van gewonne (Walker, 2003:5). In mediese terme word kanker aan 'n wanfunksie ten opsigte van seldeling binne die menslike liggaam toegeskryf (Barraclough, 2000:vii). Kanker is derhalwe 'n generiese term wat as benaming vir ongeveer 200 kwaadaardige toestande in verskillende weefsels of die bloed gebruik kan word. By elkeen van die variante is die gemene deler egter dat ongekontroleerde seldeling begin het. Die tempo waarteen die vermeerdering van hierdie selle plaasvind, is nie noodwendig vinnig nie, maar onvanpas (Souhami \& Tobias, 1998:23). Kanker kan in enige weefsel 
van die liggaam ontwikkel waar 'n afwykende sel begin verdeel. Dit is dus ten diepste 'n siekte van die selle in die liggaam - selle wat van hulle normale struktuur afgewyk het.

Die rookgewoonte, oormatige blootstelling aan die son (bestraling) of blootstelling aan skadelike chemiese stowwe soos asbes, word vir jare reeds as eksterne faktore beskou wat tot die ontstaan van kanker bydra (Delfino \& Day, 2006:5). Nie alle vorms van kanker kan egter aan eksterne faktore verbind word nie. Omdat kanker sy oorsprong in ongekontroleerde seldeling het, moet ander faktore wat hierdie seldeling aktiveer ook in ag geneem word. Persoonlikheidseienskappe soos melankolie en leefstylfaktore soos die blootstelling aan oormatige stres en trauma, tree hier op die voorgrond. Eysenck (1988:130) wys daarop dat daar sedert die tyd van Hippokrates positiewe verbande tussen 'n psigiese toestand soos hopeloosheid en kanker gelê word. Jonger navorsing op die terrein van sellulêre mikrobiologie steun hierdie beginsel in soverre dit aandui dat psigiese faktore soos stres en trauma die groei en samestelling van selle beïnvloed, wat uiteindelik bepaalde implikasies vir immuniteit en die vatbaarheid vir kanker en hartsiektes het (vgl. Dantzer, 1993:179; Steptoe, 1998:471; Blows, 2005:87) - vandaar die paradoksale aard van hierdie siekteverskynsel. Mense wat dit sogenaamd nie verdien nie deur eksterne risiko's soos rook en besoedeling te vermy, kan ook kanker kry as gevolg van bogenoemde faktore. Hierdie paradoks impliseer dat kanker 'n siekteverskynsel is wat nie net 'n mediese krisis nie, maar ook 'n psigologiese en geestelike krisis verteenwoordig (Brunsdon, 2006:47).

\subsection{Die onmiddellike implikasie van kanker}

Die diagnose van kanker noodsaak 'n mediese respons. Op grond van die opinie dat kanker in beginsel 'n behandelbare mediese toestand is (Philips, 2007:109), soek die meeste gediagnoseerde persone dadelik mediese hulp. Die belangrikste onmiddellike implikasie van ' $n$ kankerdiagnose is dus die feit dat pasiënte en hulle naasbestaandes die onbekende mediese- en emosionele arena van die kankeromgewing betree.

\subsection{Algemene vorms van mediese ingryping}

Dit is belangrik dat die pastoraat homself sal vergewis van die verskillende tipes mediese ingryping waaraan die kankerpasiënt onderworpe kan wees, aangesien dit ook 'n invloed sal hê op die pasiënt se emosionele en fisiese belewenisse ten opsigte van kanker. Alhoewel daar tans baie verskillende vorms van behandeling be- 
kend is, waaronder beenmurgoorplantings, hormoon- en immuniteitsbehandeling (Grant, 2008:961), sal slegs die drie bekendste behandelingsvorms kursories toegelig word, te wete chirurgiese ingryping, radio- en chemoterapie.

\subsubsection{Chirurgie}

Chirurgie is die oudste vorm van kankerbehandeling. Dit speel 'n belangrike rol tydens die diagnostiese fase en om vas te stel in watter mate die kanker versprei het (Rowswell, 2007:196). Alhoewel chirurgie oor die algemeen baie traumaties is, oorweeg pasiënte eerder 'n operasie as om die risiko van die verspreiding van die kanker te loop. Barraclough (2000:24-25) wys daarop dat die vooren na-operatiewe fases van chirurgie belangrike tydperke verteenwoordig waartydens terapeutiese insette gemaak kan word, aangesien albei hierdie periodes met ' $n$ verhoogde vatbaarheid vir angs en depressie gepaard gaan. In hierdie periode het pasiënte baie vrese: die operasie self, dít wat die chirurg tydens die prosedure mag ontdek, asook die emosionele en fisiese aanpassings wat in die lig van die verwydering van die betrokke organe of ledemate gemaak moet word, is alles aspekte wat vrees by pasiënte na vore bring.

\subsubsection{Radioterapie}

Radioterapie, beter bekend as bestraling, behels die hoë-energie bestraling van weefsel met die doel om die aangetaste weefsel te vernietig deur die metaboliese aktiwiteit van kankerselle te wysig (Phillips, 2007:112). Dit word veral gebruik om dele te behandel wat nie chirurgies verwyder kon word nie, omdat dit te na aan ander organe geleë is. Anders as chirurgie, verteenwoordig bestraling nie ' $n$ onmiddellike bedreiging vir die pasiënt nie, aangesien die toediening nie pynlik is nie. Die radiologiese omgewing is egter intimiderend en persone wat aan engtevrees ly, mag die prosedure negatief beleef. Een van die negatiewe gevolge van bestraling is dat dit nie slegs die aangetaste weefsel vernietig nie, maar ook gesonde weefsel. Bestraling word derhalwe gewoonlik in klein dosisse oor langer tydperke toegedien om die skade aan gesonde weefsel te beperk. Die nadeel hiervan is dat pasiënte wat ver van radiologiese fasiliteite woon, vir lang periodes van die huis af weg moet wees.

Ander gevolge wat met radioterapie in verband gebring word, is teerheid en brand van die velarea waar die bestraling gedoen is, asook 'n algemene gevoel van moegheid. Wanneer die hoër-buik bestraal word, het dit dikwels naarheid tot gevolg, terwyl diarree 
dikwels met bestraling van die laer-buik geassosieer word. Haarverlies kom voor wanneer bestraling van die kop gedoen word. Van die hewiger nagevolge van bestraling kan steriliteit by albei geslagte wees, na gelang van die gebied wat bestraal is en die intensiteit van die dosis (Brennan, 2005:229).

\subsubsection{Chemoterapie}

Hierdie vorm van terapie staan ook as sitotoksiese behandeling bekend. Dit is gerig op die verandering of doding van abnormale selle. Chemoterapie vind dikwels as die toediening van 'n kombinasie van verskillende chemiese stowwe plaas (Bevan, 2004:1025). Hierdie toediening geskied intraveneus oor siklusse van verskeie weke.

Chemoterapie vernietig sowel aangetaste as gesonde selle en is bekend vir 'n verskeidenheid gevreesde newe-effekte. Van die bekendste is naarheid, haarverlies, diarree, mondsere en moegheid (Rowswell, 2007:201). Omdat die behandeling siklies is, is dit nie net fisies uitputtend nie, maar 'n voortdurende herinnering vir die pasiënt dat hy/sy ernstig siek is.

\subsection{Sleutelveranderings in die onmiddellike leefwêreld van die individu}

In die lig van die voorafgaande is dit belangrik om op 'n praktiese vlak te poog om die veranderings wat 'n kankerdiagnose in persone se lewens bewerkstellig, te konkretiseer. Sleutelveranderings word binne die pastorale raamwerk van hierdie artikel in die volgende areas geantisipeer: wysiging van die pasiënt en naasbestaandes se gewone lewensgrense, verhoudings, gevoelens van verwerping, identiteit, kommunikasie, die waarde van tyd, angs en geloofsvrae.

\subsubsection{Verskuiwing van grense}

Sodra kanker by 'n individu gediagnoseer word, kan 'n onmiddellike wysiging van grense geantisipeer word. Hiermee word bedoel dat bykans al die kort- en langtermyn doelwitte van mense deur 'n kankerdiagnose geraak word. Die bekende roetine, beplande projekte en alle ander aktiwiteite is skielik onderworpe aan toetse, behandeling en ander dringende vereistes wat 'n kankerdiagnose meebring. "The illness violates the most basic assumptions by which people have lived their lives." (Brennan, 2005:25.) 


\subsubsection{Blootstelling aan nuwe verhoudings}

Die kankermilieu is gevul met mediese personeel met wie nuwe verhoudings ontstaan vir so lank as wat die behandeling duur. Die aanknoop van hierdie nuwe verhoudings en die vestiging van nuwe vertrouensverhoudings, plaas baie druk op pasiënte - veral in die lig van spanning wat alreeds op hulle rus op grond van die kankerdiagnose (Woodruff, 2004:451). Hierdie verhoudings leen hulle veral daartoe dat die pasiënt blootgestel voel, veral in akademiese mediese instansies waar pasiënte binne 'n opleidingsopset behandeling ontvang. Alhoewel mediese personeel normaalweg ingestel is op die gemak van pasiënte, bring 'n kankerdiagnose groot stremming in terme van verhoudings mee.

\subsubsection{Gevoelens van verwerping}

Die veranderde staat wat kanker meebring, hetsy fisies of emosioneel, veroorsaak gevoelens van vervreemding en verwerping by die pasiënt. Omdat kanker dikwels met die amputasie van ledemate gepaardgaan, kan dit maklik gebeur dat die pasiënt voel dat naasbestaandes hulle verwerp. Mans, sowel as vroue se selfbeeld en eiewaarde rus swaar op die heelheid van hulle liggaamsbeeld en die goeie funksionering daarvan (Buchbinder, 1998:353-363). Dit is deels waarom 'n vrou wat 'n mastektomie ondergaan het, so swaar by die verlies van ' $n$ liggaamsdeel aanpas (Crafford, 2004:573-584). Die diagnose van kanker en die veranderde liggaamsbeeld wat dit dikwels tot gevolg het, plaas baie druk op die naasbestaandes van pasiënte, aangesien hulle hulle eie skok oor 'n diagnose of veranderings moet hanteer, sonder om die gevoel van verwerping by die pasiënt te versterk (Wells \& Turney, 2001:31). Naasbestaandes kan egter ook deur die pasiënt verwerp voel, sodra die kankergeaffekteerde nie meer sy/haar bekende rolle kan vertolk nie. Dit geld veral ten opsigte van jonger kinders wat moeilik verstaan waarom pasiënte nie meer bekende take kan uitvoer nie (Hermann, 2001: 77).

\subsubsection{Identiteitskrisis}

Die identiteitskrisis wat hier ter sprake is, staan hoofsaaklik in verband met die kankerlyer se siening van hom-/haarself nadat kanker gediagnoseer is. Skielik is die beeld in die spieël nie meer dieselfde as tevore nie. Die kankerpasiënt beleef moontlik ook 'n inperking ten opsigte van fisiese vermoëns. Dit laat die kankerlyer in 'n identiteitskrisis rondom die self beland (Brennan, 2005:73). 


\subsubsection{Radikalisering van kommunikasie}

Kanker dompel pasiënte in 'n kommunikasiekrisis (Louw, 1994:115). In die vroeë fases van toetsing en diagnosering, kan medici huiwerig wees om hulle oor die pasiënt se toestand uit te spreek. Onderliggende vrese kan die pasiënt verhoed om werklik die vrae te vra wat op hulle harte druk. Die stigma en vrese omtrent kanker kan ook die onmiddellike familie verhinder om die vermoedelike probleem enigsins met die pasiënt te bespreek. Hierdie faktore plaas kommunikasie vir die pasiënt binne 'n problematiese raamwerk.

\subsubsection{Radikalisering van tyd}

Vir kankerpasiënte is daar dikwels lang wagperiodes tussen toetse wat hulle in 'n toestand van "vrees vir die ergste en hoop vir die beste" laat beland (Louw, 1994:117). Hulle bestaansreg word in 'n sekere sin deur die gunstige uitslag van toetse gesanksioneer. Dit bring mee dat tyd vir die kankerpasiënt binne 'n nuwe raamwerk van kosbaarheid, bedreiging en onsekerheid staan, aangesien hulle voortdurend onseker is oor die hoeveelheid tyd waaroor hulle beskik en ook wat die kwaliteit daarvan gaan wees.

\subsubsection{Skeidings- en doodsangs}

Die algemene opvatting omtrent 'n kankerdiagnose is steeds dat dit gelykstaande is aan 'n doodsvonnis. Louw (1994:116) poneer: "Cancer places every sufferer in a crisis between life and death. In a certain sense cancer radicalises one's awareness of mortality, which in suffering, could revert to death anxiety." Skeidingsangs is hierby inbegrepe aangesien die dood en skeiding van die bekende hand aan hand loop.

\subsubsection{Geloofsvrae}

Uit die voorafgaande blyk dit duidelik dat die realiteit van kanker 'n eksistensiële krisis in die lewens van mense kan veroorsaak. Dit is gewoonlik in die aangesig van eksistensiële problematiek dat mense geloofsvrae begin vra. Veral wanneer hulle met hulle eindigheid en die oënskynlike onverklaarbaarheid van 'n siekte soos kanker gekonfronteer word, neig mense tot geloofsvrae (Alberts, 1993:215). Met geloofsvrae word gedink aan die godsdienstige vrae wat mense in die aangesig van kanker vra. Hierdie vrae sal in alle waarskynlikheid op ten minste twee vlakke lê, naamlik op 'n persoonlikreligieuse sowel as 'n algemeen-religieuse vlak. Met geloofsvrae op 'n persoonlik-religieuse vlak word gedink aan vrae soos: "Wat het ek gesondig dat God my op hierdie manier wou straf?" Geloofsvrae op 
algemeen-religieuse vlak verwys na die teodiseevraagstuk, naamlik hoe ellende met die bestaan van God versoen kan word (die teodisee vraag word in die volgende paragrawe breedvoeriger bespreek). Om geloofsvrae in die lig van eksistensiële nood te vra, hoef iemand nie noodwendig aan die Christelike geloof verbonde te wees nie, aangesien die teodiseevraag ' $n$ universele vraag in die aangesig van rampe en teëspoed is (vgl. König, 2002).

\section{Voorlopige merkers vir die pastoraat}

In die lig van die voorafgaande is dit duidelik dat kanker 'n krisis verteenwoordig wat by pastorale ingrype kan baat. Die volgende sou as voorlopige fokuspunte vir die pastoraat binne hierdie situasie kon dien.

\subsection{Die teodiseevraag}

In die lig van die feit dat kanker as 'n lewensbedreigende siekte beskou word en lyding op die voogrond bring, sal die hantering van die teodiseevraag op die een of ander wyse as deel van die terapeutiese pad gesien moet word.

Die teodiseevraag is inherent een van die moeiliker teologiese vraagstukke. Dit verteenwoordig die eeue oue vraag oor hoe die bestaan van God met die bestaan van die slegte in die wêreld versoen kan word. Louw (2000:21) wys daarop dat die konsep van teodisee nie 'n Skriftuurlike begrip is nie, maar as filosofiese konsep deur die geskiedenis ontwikkel het om die dilemma van lyding met die bestaan van God te probeer versoen. Indien hierdie begrip letterlik verstaan word, kom dit egter neer op 'n poging om God en sy handelinge te regverdig (Woodall, 2004:28). Van vroegs af is so 'n letterlike verstaan van die teodiseevraag as 'n teologiese anomalie beskou. Berkouwer (1950:277 e.v.) meen dat dit heiligskennis is om God te probeer regverdig. Ook Heyns (1988:163) sê dat die mens nie vanuit die sondegebroke werklikheid kan klim tot die regverdiging van God se handelinge nie. Dit is in hierdie lig te verstane dat Hauerwas (1990:ix) populêre pogings soos Kushner se When bad things happen to good people 'n "theological mistake" noem. Dit wil dus voorkom dat die pastor se taak in hierdie verband nie is om as apologeet vir God se handelinge op die siek persoon se hoekomvrae op te tree nie. "[T]heoretical attempts to justify God logically cannot create hope, because it will only create new cognitive inconsistencies." (Vorster, 2007:206.) 
Waar die pastorale gesprek in die rigting van die teodiseevraag stuur, behoort dit eerder met inagneming van die volgende merkers uit die huidige teodiseediskoers op heuristies-hermeneutiese wyse benader te word. Op hierdie wyse word die lydende persoon gehoor en die pastorale proses word 'n geleentheid om soekend saam op weg te wees binne die lydende se unieke situasie.

\section{- Die hoekom- en waaromvraag is nie vreemd aan menswees of die Woord nie}

Hauerwas (1990:x) wys daarop dat die behoefte om hoekom en waarom in die lig van lyding te vra as 'n primitive need van die mens beskou kan word. Ook in die lig van die Skrif (Ps. 13; 73) blyk duidelik dat mense in moeilike omstandighede vrymoedig hierdie vraag gevra het. Die pastor hoef dus nie in die afwesigheid van finale antwoorde weg te skram van die teodiseevraag nie, maar behoort ruimte te skep sodat die noodlydende onbevange hulle vrae kan verbaliseer.

\section{- Die teodiseevraag noodsaak 'n verruimde beskouing van siekte}

Die teodiseevraag raak gevaarlik vir die mens se geloof wanneer 'n moralistiese siening op siekte nagehou word. Dit beteken dat siekte altyd as die gevolg van 'n spesifieke immorele optrede beskou word. Hierdie siening beteken dat die sieke iewers 'n (persoonlike) skuldlas wil lê om die situasie te verklaar. Wanneer siekte as deel van die breër gebroke werklikheid aanvaar word (Carson, 1999:43), bestaan daar minder druk om te verklaar waar dit vandaan kom. Van Niekerk (2005:618) se mening dat die kwaad 'n misterie is, is hier van waarde. Wat ons van die kwaad/lyding weet, is versluierde kennis. Selfs al sê die Bybel baie oor kwaad, kan ons nie genoeg daaroor aflei om klinklare en finale antwoorde oor die redes en sin daarvan te gee nie. Dit wil dus voorkom of dit meer sinvol sou wees om berusting daaroor te soek in die lig van ons voorlopige en gebroke bestaan hier op aarde.

\section{- Die teodiseevraag noodsaak 'n verruimde godsbeskouing}

Louw (1994:12-13) lê 'n duidelike verband tussen die volwassenheid van mense se geloof en hulle godsbeskouing. Hoe die persoon wat deur 'n ernstige siekte geraak word, vir hom-/haarself die teodiseevraag uitmaak, sal dus te make hê met die beeld van God wat dominant in hulle geloof funksioneer (Boyd, 2003:15). lemand wat God oorwegend as regter sien, sal lyding vermoedelik as God se (regverdige) oordeel ervaar en aanvaar. Dit is derhalwe belangrik 
om vas te stel watter godsbeeld dominant in iemand se lewe is sodat daardie beeld in ooreenstemming met die Skrif verruim kan word om uiteindelik God se rol in lyding duideliker te probeer maak.

\section{- Daar is nie 'n finale antwoord op die hoekom- en waaromvrae nie}

Wanneer die Bybelse locus classicus van die teodiseevraagstuk (Weiser, 1986:507) in Psalm 73 ontleed word, is dit betekenisvol dat Asaf nie 'n antwoord op die vraag waarom die goddelose floreer en hy lyding ervaar, kry nie. Hy kry bloot die geloofsversekering dat God met hom op weg is en dat die troue Bondsgod hom deur hierdie worsteling aan die hand gehou het (Ps. 73:23). Dit is belangrik om daarop te let dat God in hierdie Psalm (en ook ander voorbeelde, soos by Job) as die handelende party geteken word. Die troos in tye van ernstige siekte is dus nie soseer in antwoorde op die vrae geleë nie, maar in God se bondstrou wat ons deur die krisis dra.

Die pastor sal egter baie sensitief moet wees vir die feit dat dit vir die gelowige kankerpasiënt belangrik sal wees om te weet waar God in hierdie situasie staan en dat hy/sy daarmee erns sal moet maak om hierdie behoefte by die pasiënt en sy/haar naasbestaandes te erken en daaroor te praat.

\subsection{Die lydingsvraagstuk}

Baie nou verweef met die teodiseevraagstuk, is die kwessie van lyding. In die literatuur loop hierdie sake in só 'n mate hand aan hand dat dit as twee kante van dieselfde munt beskou kan word. Met wat reeds oor kanker geskryf is, word van die veronderstelling uitgegaan dat kanker in die teken van lyding staan. $\mathrm{Al}$ is dit nie terminaal nie, is die behandeling self ' $n$ vorm van lyding.

Lyding is 'n universele verskynsel. Dit is ook nie vreemd aan die Woord nie (Heystek, 1999:51; De Kock, 2007:181). In sy aantekeninge oor die lewe van Job, sê Van der Zee (1985:11): "De Bijbel kreunt daaronder." Dit is ook nie vreemd aan die ander godsdienste van die wêreld nie (vgl. ook Bowker, 1990).

Aan die hart van die lydingsvraag is die vraag na sin - die sin van die lyding en uiteindelik die sin van die lewe teen die agtergrond van lyding.

Aangesien logiese argumente en beredenerings oor die lydingsfenomeen volgens De Kock (2007:5) hoogstens tydelike troos aan die lydende bied, behoort die pastorale proses eerder na die aan- 
vaarding van lyding te mik en om die noodlydende te begelei om lyding as 'n groeiproses te sien. Louw (2000:173) sien die sin van lyding teen die agtergrond van groei na 'n volwasse geloof: "Such believers are able to integrate suffering as a task and calling through which they can grow towards maturity."

Die noodlydende kan veral teen die agtergrond van die verbond en die lyding van Christus self (Heystek, 1999:53) aangemoedig word tot die aanvaarding van lyding as roeping. Heyns (1986:495) wys daarop dat God in sy almag nie magteloos teenoor lyding of die gebroke werklikheid staan nie, maar daaroor heers en dit selfs in sy diens gebruik (Amos 3:6 e.v.; Jes. 45:7; Matt. 26:56). Dit is dus "onmogelijk om God buiten mijn lijden te houden" (Matti, 1995:92). Die Woord onderstreep die beginsel van lyding baie duidelik en stel dit as een van die onvermydelikhede in die sonde-aangetaste wêreld. Die feit dat die mens binne die gebroke werklikheid wel binne die raamwerk van God se verbond leef, gee 'n ander kwaliteit aan lyding. Die Verbondsgod van die Woord is immers die Here wat in tye van nood met die mens op weg gaan (Janse van Rensburg, 1996:154). Die noodlydende kan dus in tye van nood met God praat en deur die sekuriteit van God se verbondstrou gedra word.

\subsection{Die sonde-siekteverhouding}

Nou verweef met die teodisee- en lydingsvraagstuk is die vraag: "Wat het ek gedoen dat God my so straf?" Hierdie vraag kom deels uit die moralistiese lewensbeskouing van die individu op en deels uit die wete dat die Skrif wel deeglik 'n verband tussen siekte en sonde lê (Ps. 38:4-5; Ps. 41:5).

Binne sommige teologiese denkrigtings word sonde en siekte as onlosmaaklik van mekaar beskou en in 'n sekere sin op die spits gedryf (Janse van Rensburg, 1999:9-10). In die lig van Skrifgedeeltes soos 2 Konings 5:26 en 1 Korintiërs 11:30, kan die kousaliteitsbeginsel nie as werkbare verklaring binne sekere omstandighede negeer word nie. Die mediese wetenskap het immers onweerlegbare verbande aangedui tussen 'n onverantwoordelike lewenstyl (rookgewoonte) en sekere vorms van kanker soos kanker van die mond, longe en keel (Alberts, 1993:11). Hieruit sou afgelei kon word dat swak rentmeesterskap van die liggaam 'n bepaalde skuldlas in die vorm van siekte kan meebring.

Louw (1984:33) wys egter hierdie kousale verklaringsmodel as pastorale hanteringsmoontlikheid af. Die gevaar is, soos in die hantering van die teodiseevraagstuk, dat 'n skuldige uitgewys moet word om 
die siekte te verklaar. Só 'n hantering van die situasie mag daarop uitloop dat die persoon hom-/haarself of God vir die situasie verwyt - en so in 'n geloofskrisis beland.

Daar sal dus na 'n begaanbare middeweg gesoek moet word om die sonde-siekteverhouding in die pastoraat aan te sny. Hierdie middeweg is heel waarskynlik te vinde in begeleiding ten opsigte van sondebelydenis en die aanvaarding van die vergifnis waarna die persoon verlang.

Hierdie belydenis moet egter nie gedoen word as 'n (desperate) poging om die siektesituasie om te keer nie, maar in die lig van die objektiewe versoeningswerk van Jesus Christus. Hierdie beginsel geld egter ook die situasie waar daar geen verband tussen 'n nalatige lewenstyl en kanker gelê kan word nie. Hierdie proses kan 'n belangrike pastorale moment in die begeleidingsproses word om die lydende persoon tot vrede en heelheid van verhoudings binne die krisissituasie te lei.

Dit is duidelik dat die vraagstuk oor die verhouding tussen sonde en siekte met versigtigheid en erns benader moet word.

\subsection{Medies-etiese vraagstukke}

Kanker bring die geaffekteerde voorts binne die arena van mediesetiese kwessies. Dean (2006:185) dui aan dat ernstige siekte implisiet etiese vrae meebring. Etiese vraagstukke in die pastoraat aan die kankergeaffekteerde moet dus sekerlik geantisipeer word. Etiese vrae binne hierdie konteks sal waarskynlik rondom drie sake wentel: Eerstens, die vrae wat net ná 'n kankerdiagnose opduik: Moet ek vir behandeling gaan of nie? Tweedens, die vrae wat opduik wanneer dit lyk asof die behandeling nutteloos is: Moet ek vir verdere behandeling gaan? En derdens, vrae wat dalk nie deur die pasiënt self geponeer sal word nie, maar deur die familie in die geval van pasiënte wat aan lewensondersteunende apparate gekoppel word: Hoe lank moet die status quo gehandhaaf word?

Verskeie outeurs oriënteer hulleself ten opsigte van hierdie kwessies aan Genesis 1:26, die beginsel dat die mens na die beeld van God geskape is, maar ook aan die sesde gebod wat handel oor die beginsel van respek vir die lewe (Murray, 1991:113; Douma, 1994: 133-180). Die redenasie is dat lewe 'n gawe van God is en sover moontlik gekoester moet word. In sy bespreking oor die etiese lewe as 'n lewe van geestelik-liggaamlike gesondheid, lê Heyns (1986: 470-487) 'n duidelike verband tussen geestelike en liggaamlike ge- 
sondheid. Tot eersgenoemde behoort 'n gesonde verhouding met die Here, soos dit onder andere tot uitdrukking kom in gebed en die ontwikkeling van die persoon as 'n geestelik volwasse mens.

Die ander kant van die munt sou wees dat die mens so goed as moontlik na die liggaam omsien, aangesien dit die raamwerk van menswees is. Sonder die liggaam kan die ek immers nie wees nie. Hoewel hierdie onderskeid geensins impliseer dat hierdie navorsings vanuit 'n digotomistiese antropologie werk nie, verdien die volgende uitgangspunte oor die mens se liggaam sekerlik aandag:

- Die liggaam is deur God geskep en moet deur die mens gerespekteer word.

- Die liggaam verteenwoordig die konkrete bestaanswyse van die mens op aarde.

- Die mens kan God deur sy liggaam verheerlik.

Dit sou egter baie eensydig wees om bloot op grond van hierdie gegewens te sê dat die mens uit respek vir die liggaam elke denkbare maatreël ten alle koste moet inspan om so lank as moontlik die liggaam aan die lewe te hou, ongeag die kwaliteit van daardie lewe en die persoon se geestelike welsyn. Dan het ons met 'n verabsolutering van die liggaam te make in weerwil van die feit dat die mens bestem is om tydelik op die aarde te wees (vgl. Ps. 90:10; 103:1516).

Dit is belangrik om te onthou dat die menslike bestaanswyse hier op aarde nooit as absoluut beskou kan word nie. Die mens is in wese ' $n$ kleipot (2 Kor. 4:7) en 'n tent (2 Kor. 5:1). Die antwoord op mediesetiese dilemmas moet dus nie gesoek word in die rigting van 'n krampagtige vasklou aan die lewe nie, maar in 'n gesonde balans tussen die wil om te lewe en die aanvaarding van die eindigheid van die liggaam.

'n Lewensbedreigende siekte soos kanker bring mense by die kruispad van die wil tot lewe, immanente lyding of selfs die dood. Praktiese leiding is dus belangrik ten einde spanning in sulke situasies te verlig. Kretzschmar en Hulley (1998:112) meen dat sinvolle besluitneming in die lig van medies-etiese kwessies begin by die reg van pasiënte en hulle gesinne om die ware toedrag van sake aangaande ' $n$ bepaalde mediese toestand te ken. Hulle tese is dat ' $n$ persoon nie goeie besluite op grond van halwe waarhede kan neem nie. Met feitelike inligting oor die prognose van 'n siekte kan mense ingeligte besluite oor die hantering van die situasie neem. 
Die gelowige kan hom/haar dus deur twee beginsels laat lei: eerstens dat die lewe inderdaad die moeite werd is (vgl. Van Bruggen, 1982), selfs in die aangesig van lyding. Indien daar 'n gunstige prognose is, sal daar uit respek vir die lewe en in verantwoordelikheid daarvoor, behandeling ondergaan moet word.

Die tweede beginsel is dat die aardse lewe nie absoluut is nie. Daarmee word die dood egter nie as 'n doel gestel waarna mense as 't ware moet uitsien nie. Heyns (1986:507) maak in hierdie verband die belangrike onderskeid dat die dood self nie die voleinding is nie, maar dat die voleinding ná die dood volg. Dit is waarna die gelowige selfs mag verlang (Fil. 1:23). Die mens het onder normale omstandighede 'n wonderlike wil om te lewe. Derhalwe sal mense selde in die beginstadium van kanker behandeling weier. Dit sou egter wreed wees om ten alle koste die uitmergelende behandeling van kanker te laat voortgaan indien dit duidelik geraak het dat die mediese hulp nie die verlangde resultate lewer nie. Daar kom dus 'n tyd waar die kankerlyer letterlik "toegelaat" moet word om te sterf - in die wete dat dit in die laaste instansie nie die mens is wat oor die lewe beskik nie, maar God self (Ps. 90:3).

\subsection{Sterwensbegeleiding en rousmart}

Kanker bring rousmart binne die gesigseinder. Dit behoort egter binne 'n breër én enger sin verstaan te word. In die breër sin word veronderstel dat kanker afskeid oor 'n breë spektrum meebring. Daar word tydelik of permanent afskeid geneem van die normale bestaanswyse - alles waaraan die lydende gewoond was. In hierdie sin sal daar ' $n$ rouproses by die lydende teenwoordig wees wat deur die pastoraat gefasiliteer behoort te word. Wanneer dit enger verstaan word, kom die sterwensbegeleidingsproses ook in die oog indien die kanker terminaal blyk te wees en nie by mediese ingrype gebaat het nie. Hiermee betree die pastorale proses sy laaste taak sover dit die kankerpasiënt self raak. In die lig van die onafwendbaarheid van die dood (Phillips, 2007:55) moet die pastor iewers binne die pastorale proses hierop voorbereid wees.

\subsection{Eskatologiese bestemming}

As ons lewe, leef ons tot eer van die Here; en as ons sterwe, sterf ons tot eer van die Here. Of ons dan lewe en of ons sterwe, ons behoort aan die Here. (Rom. 14:8.)

Deur die genadevolle werk van Jesus Christus het die gelowige 'n eskatologiese verwagting wat die angel uit die aardse dood verwyder (1 Kor. 15:55). Die uitdaging met kanker is juis om hierdie troos 
op effektiewe wyse aan die lydende oor te dra. Pastoraat wat in gebreke bly om geloofsorg (Louw, 1989:4) te verleen en promissioterapie (Louw, 1984:56-60) uit die oog verloor, mag dui op 'n verskraling van pastorale hulpverlening aan die sieke.

Die heerlike en unieke bydrae van die pastoraat is juis daarin geleë dat dit die beloftes van 'n nuwe hemel en aarde mag verwoord, waar trane en pyn afwesig is en God self by die gelowige aanwesig is (Op. 21:4).

\section{Gevolgtrekking}

Deur die voorafgaande beredenering en toeligting van kanker is aangedui dat hierdie siekte ' $n$ bestaanskrisis in die lewe van persone veroorsaak wat daardeur getref word. Die omvang van hierdie krisis lê nie net op die vlak van fisiese ontberings nie, maar veral ook op 'n geloofs- en eksistensiële vlak. Die pastor wat op weg met die kankergeaffekteerde gaan, sal in die lig van die negatiewe diskoerse en radikaliteit van die behandeling, veral fokus op die krisisse wat kanker meebring. Ses areas is vir die pastorale proses geïdentifiseer, naamlik die teodiseevraagstuk, lyding, die sondesiekteverhouding, medies-etiese vraagstukke, sterwensbegeleiding en rousmart en die eskatologiese eindbestemming van die mens. Hierdie areas is in die lig van die voorafgaande beredenering waarskynlike fokusareas vir die pastoraat. Waarskynlik is dit wel nie die enigstes nie. Die pastor, gekonfronteer met begeleiding van die kankergeaffekteerde, behoort egter hierin waardevolle vertrekpunte vir die pastorale proses te vind.

\section{Geraadpleegde bronne}

ALBERTS, A.S. 1993. Knowledge beats cancer. Pretoria: HAUM.

BARRACLOUGH, J. 2000. Cancer and emotion. 3rd ed. Chichester: Wiley.

BERKOUWER, G.C. 1950. De voorzienigheid Gods. Kampen: Kok.

BEVAN, D.H. 2004. Haematological disease. (In Axford, J. \& O'Callaghan, C., eds. Medicine. 2nd ed. Malden: Blackwell Science. p. 994-1077.)

BLOWS, W.T. 2005. The biological basis of nursing: cancer. London: Routledge.

BOWKER, J. 1990. Problems of suffering in religions of the world. Cambridge:

Cambridge University Press.

BOYD, G.A. 2003. Is God to blame? Downers Grove: InterVarsity.

BRENNAN, J. 2005. Cancer in context: a practical guide to supportive care. Oxford: Oxford University Press.

BRUNSDON, A.R. 2006. Pastoraat aan die afgetrede egpaar deur kanker geaffekteer: 'n narratiewe benadering. Bloemfontein: Universiteit van die Vrystaat. (Ph.D.-proefskrif.) 
BUCHBINDER, D. 1998. A well-shaped man. (In Petersen, A. \& Waddel, C., eds. Health matters. Buckingham: Open University. p. 353-363.)

CARSON, D.A. 1999. How long, o Lord? Grand Rapids: InterVarsity.

CRAFFORD, J.D. 2004. Die groei van hoop na mastektomie. Nederduitse Gereformeerde teologiese tydskrif, 45(3 \& 4):573-584.

DANTZER, R. 1993. Coping with stress. (In Stanford, S.C. \& Salmon, P., eds. Stress: from synapse to syndrome. London: Academic Press. p. 167-190.)

DE KOCK, D.J. 2007. Pastorale begeleiding van gesinne met betrekking tot die sin van lyding by gestremdheid. Potchefstroom: Noordwes-Universiteit. (Ph. D.-proefskrif.)

DEAN, M. 2006. Symptom relief in palliative care. Oxford: Radcliffe Publishing.

DELFINO, M. \& DAY, M.E. 2006. Cancer: we live and die by radiation. Los Altos: MoBeta.

DOUMA, J. 1994. De tien geboden. DI. 2. Kampen: Uitgeverij Van den Berg.

EYSENCK, H.J. 1988. Personality and stress in cancer and coronary heart disease. (In Janisse, M.P. Individual differences, stress, and health psychology. New York: Springer. p. 129-145.)

GRANT, B. 2008. Medical nutrition therapy for cancer. (In Mahan, L.K. \& EscottStump, S., eds. Krause's food and nutrition therapy. 12th ed. St. Louis: Saunders/Elsevier. p. 959-990.)

HAUERWAS, S. 1990. Naming the silences: God, medicine and the problem of suffering. Grand Rapids: Eerdmans.

HERMANN, J.F. 2001. Children of cancer patients: issues and interventions. (In Lauria, M.M., Clark, E.J., Hermann, J.F. \& Stearns, N.M., eds. Social work in oncology: supporting survivors, families and caregivers. Atlanta: American Cancer Society. p. 73-92.)

HEYNS, J.A. 1986. Teologiese etiek. Pretoria: NG Kerkboekhandel.

HEYNS, J.A. 1988. Dogmatiek. Pretoria: NG Kerkboekhandel.

HEYSTEK, P.H. 1999. Herderlike bediening aan verbondsouers van 'n kind met downsindroom. Potchefstroom: Noordwes-Universiteit (Th. M.-skripsie.)

JANSE VAN RENSBURG, J. 1996. Verbond en pastoraat: perspektiewe vir die ontwerp van 'n paradigma. Nederduitse Gereformeerde teologiese tydskrif, 38(1):152-165.

JANSE VAN RENSBURG, J. 1999. The occult debate. Kaapstad: Lux Verbi.

KÖNIG, A. 2002. God, waarom lyk die wêreld so? Parow: Lux Verbi.BM.

KRETZSCHMAR, L. \& HULLEY, L., eds. 1998. Questions about life and morality. Pretoria: Van Schaik.

KRÜGER, P.A. 1987. Habakuk. Kaapstad: NG Kerk-Uitgewers.

LOUW, D.J. 1984. Pastoraat in eskatologiese perspektief. Kaapstad: NG KerkUitgewers.

LOUW, D.J. 1989. Die ontwerp van 'n teologiese antropologie as basisteorie vir 'n effektiewe pastorale bediening. (In Smuts, A.J., ed. Predikant en pastorale praktyk. Pretoria: Academica. p. 4-35.)

LOUW, D.J. 1994. Illness as crisis and challenge. Doornfontein: Orion.

LOUW, D.J. 1998. Pastoraat as vertolking en ontmoeting: teologiese ontwerp vir basisteorie, antropologie, metode en terapie. Kaapstad: Lux Verbi.

LOUW, D.J. 2000. Meaning in suffering: a theological reflection on the cross and the resurrection for pastoral care and counselling. Frankfurt am Main: Peter Lang.

MATTI, A. 1995. Wat het je aan je geloof als lijden je treft. Baarn: Ten Have. 
MEUNIER, F. 2007. Klinische studies naar kanker in Europa, uitdagingen en mogelijkheden. http://www.europadonna.be/nl/edb.Presentation.html Date of access: 19 Apr. 2008.

MURRAY, J. 1991. Principles of conduct: aspects of Biblical ethics. Grand Rapids: Eerdmans.

BYBEL. 1953. Ou Afrikaanse Bybelvertaling. Kaapstad: Bybelgenootskap van Suid-Afrika.

BYBEL. 1983. Nuwe Afrikaanse Bybelvertaling. Kaapstad: Bybelgenootskap van Suid-Afrika.

NAV

OAV

kyk BYBEL. 1983.

kyk BYBEL. 1953.

PHILLIPS, N. 2007. Berry \& Kohn's operating room technique. 11th ed. St. Louis: Mosby.

ROWSWELL, M. 2007. Caring for the patient with cancer. (In Walsch, M. \& Crumbie, A., eds. Watson's clinical and related sciences. 7th ed. Edinburgh: Baillière. p. 187-243.)

SOUHAMI, R.L. \& TOBIAS, J. 1998. Cancer and its management. 3rd ed. Oxford: Blackwell Science.

STEPTOE, A. 1998. Coping, control and health risk. (In Csermely, P., ed. Stress of life: from molecules to man. New York: New York Academy of Sciences. p. 470-476.) (Annals of the New York Acadamy of Sciences, 851.)

VAN BRUGGEN, J. 1982. Het leven is de moeite waard. Rotterdam: De Vuurbraak.

VAN DER ZEE, W.R. 1985. Wie heeft daar woorde voor? 's-Gravenhage: Boekencentrum.

VAN NIEKERK, A.A. 2005. Teodisee en misterie: oor God, kwaad en lyding. Nederduitse Gereformeerde teologiese tydskrif, 46(3 \& 4):609-622.

VAN PELT, J.W. 1999. Pastoraat in trinitarisch perspectief: de samehang van trinitarische en antropologische aspecten in het pastoraat. Heerenveen: Groen.

VORSTER, N. 2007. The problem of theodicy and the theology of the cross. In die Skriflig, 41(2):209-231.

WALKER, M. 2003. German cancer therapies. New York: Twin Streams.

WEISER, A. 1986. The psalms. Norwich: SCM.

WELLS, N.L. \& TURNEY, M.E. 2001. Common issues facing adults with cancer. (In Lauria, M.M., Clark, E.J., Hermann, J.F. \& Stearns, N.M., eds. Social work in oncology: supporting survivors, families and caregivers. Atlanta: American Cancer Society. p. 27-44.)

WOODALL, C. 2004. The theology of theodicy: a doctrinal analysis of divine justice in the light of human suffering. Potchefstroom: NoordwesUniversiteit. (Ph.D.-proefskrif.) (Ongepubliseerd.)

WOODRUFF, R. 2004. Palliative medicine. 4th ed. Melbourne: Oxford University Press. 


\section{Key concepts:}

cancer

ethical issues

pastorate

suffering

theodicy

Kernbegrippe:

etiese vraagstukke

kanker

lyding

pastoraat

teodisee 
